\title{
Information literacy through resource-based learning: Malaysian teachers' conception and instructional practices
}

\author{
Halida $\mathbf{Y u}^{1}$, A. Abrizah ${ }^{2}$ and Mad Khir Johari Abdullah Sani ${ }^{1}$ \\ ${ }^{1}$ Faculty of Information Management, \\ University Teknologi MARA, Shah Alam, Selangor, MALAYSIA \\ ${ }^{2}$ Department of Library \& Information Science, \\ Faculty of Computer Science \& Information Technology, \\ University of Malaya, Kuala Lumpur, MALAYSIA \\ e-mail: halidayu@yahoo.com (corresponding author); \\ abrizah@um.edu.my; madkhir@yahoo.com
}

\begin{abstract}
This paper examines how secondary school teachers in Malaysia conceptualize information literacy, and how this understanding leads to information literacy practices through resource-based learning. Although there have been studies carried out in this area, most of the studies are conducted in western societies with sound exposure to information literacy. This study takes place in a learning environment where information literacy is not a central focus in the school curriculum. It employs a qualitative approach in the form of a case study. Five history subject teachers supervising resourcebased learning history project took part in the study. Data were collected through a series of interviews with the teacher participants to uncover: (a) their conceptions of information literacy; (b) their teaching focus in the project instruction; and (c) the instructional approach employed. Six information literacy conceptions, six information literacy teaching focuses, and four types of information literacy instructional methods are generated from the study. The findings suggest that the teachers' conceptions of information literacy in Malaysia are quite comparable to those from developed countries. However, the outlooks are more superficial and lack richness and depth. Further findings show that these conceptions influence and shape teachers' information literacy teaching focuses, as well as their project instructional approaches.
\end{abstract}

KEYWORDS: Information literacy instruction; Information literacy conception; Instructional approaches; Resource-based learning; Secondary schools.

\section{INTRODUCTION}

Information literacy is a critical skill to have in order to thrive in today's information-rich environment. This view is repeatedly highlighted in numerous documents (AASL Standards for the 21st Century Learner (ALA) 2008; Information power (AASL) \& (AECT), 1998; Australian and New Zealand Information Literacy Framework (ANZIL) and (CAUL) 2004; and Understanding Information Literacy UNESCO 2007). Emphasis on student-centred and selfdirected learning through resource-based learning approach in today's education system has further exerted increasing pressure on the necessity to educate secondary school students on information literacy in the recent years. Accordingly, numerous information literacy programmes have been introduced in what appear to be serious concerns to produce an information literate young generation. Despite these efforts, studies (Jackson 2006; Julien and Barker 2009; Meyers and Eisenberg 2008; Williams and Wavell 2006) 
point out that many graduating secondary school students are not well-equipped with information literacy skills. This calls for more attention to explore information literacy practices and experiences to get a more holistic picture of the state of information literacy instruction in schools. The first step to this pursuit begins with the examination of teachers' conceptions of information literacy. Moore $(2000 ; 2002)$ and Williams and Wavell (2006) have shown close relationship between teacher's conceptions of information literacy and effective information literacy instructions in the classrooms, Although information literacy instruction in schools is a joint responsibility of many parties (such as teachers and teacher-librarians) classroom teachers are believed to be the most influential to the students as they are the ones spending the most time with students in classrooms (Smith 2013; Williams and Wavell 2006).

This study examines how subject teachers conceptualize information literacy, and how they teach the skills through a resource-based history project in secondary schools in Malaysia. Although a growing number of studies investigate classroom teachers' conceptions of information literacy, most of these studies take place in learning environment where the curriculum are information literacy-focused, mostly in the more developed countries (Probert 2009; Smith 2013; Williams and Wavell 2006). Moreover, these studies only focus on the variations of teachers' information literacy conceptions but do not examine how these conceptions implicate and influence teachers' teaching focuses and approaches in teaching information literacy. Missing from the discussions is how conceptions of information litearcy influence information literacy instructions through classroom assignments, particularly, in the learning contexts where information literacy is not the central focus of the curriculum. Therefore this paper attempts to discuss teachers' understanding of information literacy and their approaches to teach information literacy through resource-based learning in learning contexts where students' exposure to information literacy is less evident. The findings from this study is hoped to provide baseline information on information development in learning contexts where information awareness is low.

\section{LITERATURE REVIEW}

\section{Teachers' Conceptions of Information Literacy}

Studies focusing on teachers' understanding of information literacy have revealed the teachers' confusions and misunderstandings of the skill. An evident finding that emerged is that many teachers are either not clear or misunderstand "Information literacy" themselves (Chan 2002; Macklin 2001; Probert 2009; and Williams and Wavell 2006). Studies disclose that many teachers misconstrue information literacy as ICT skills, (Bruce 1997; Macklin 2001; Yu et. al. 2011; Williams and Wavell 2006), with a number of thembraggingabout how their students are competent Web-information seekers, needing little help from them. Macklin (2001) adds that some teachers even question the need for students to learn information literacy skills when they already know how to use the Internet.

A number of studies venture into figuring out educators' understanding of information literacy (Boon, Johnston and Webber 2007; Bruce 1997; Smith 2013; Webber and Johnston 2000; Williams and Wavell 2006; Yu et. al. 2011). Bruce's and Williams and Wavell's studies are particularly important work in this area. Findings from Bruce's study earn her the famous "Seven Faces of Information Literacy" framework, in which, she demonstrates seven variations of teachers' conceptions of the skills. They are; (a) information technology 
conception; (b) information sources conception; (c) information process conception; (d) information control conception; (e) knowledge construction conception; (f) knowledge extension conception; and (g) wisdom conception. Williams and Wavell's study (2006) generates six conceptions of students' information literacy framework, namely: (a) finding information conception; (b) linguistic understanding conception; (c) making meaning conception; (d) practical skills conception; (e) critical awareness of sources conception; (f) independent learning conception. The study took place in secondary schools in eight localities in the United Kingdom. Another similar study is that by Boon, Johnston and Webber (2007) in which the researchers explore English faculty academicians' conceptions of information literacy. They find that information literacy is still perceived as a new area in the English study discipline.The academicians are also found to pay little attention to the skills. Findings from the study reveal four different variations of information literacy conceptions; (a) accessing and retrieving textual information; (b) using ICT to access and retrieve information; (c) possessing basic research skills and knowing how and when to use them; and (d) becoming confident autonomous learners and critical thinkers. The findings demonstrate both similar and significantly different conceptions that are found in other frameworks. Results from three other studies (Moore 2000; Yu et. al. 2011) also demonstrate the fact that teachers have much limited understanding of information literacy, mainly, revolving around information literacy as ICT and finding information.

\section{Teachers' Perceived Roles to Teach Information Literacy}

Increasing concern on real 'information literacy practices and learning'rather than merely 'library information seeking' experiences have seen growing studies examining information literacy integration through school assignments. Many of these studies (Bawi 2002; Hart 2000; Jackson 2006; Mc Kenzie 2000; Williams and Wavell 2006) reveal that students receive inadequate information literacy guidance for their information-based tasks. In short, the researchers, regardless of their background, find that students receive little guidance on how to work on their projects. Findings from some studies (Jackson 2006; Macklin 2001; Probert 2009) also disclose that many teachers believe that there is little need for them to help their students as the students already possess excellent information seeking and locating skills. Similarly, Macklin (2001) and Williams and Wavell (2006) reveal that some teachers assume that students already have the necessary skills to work on their tasks. This supposition is another factor hindering the teachers from assisting the students with information literacy and their project. Further studies (Bawi 2002; and Hart 2000) show that subject teachers merely focuse on the subject-matter of their students' task, and do not address information literacy elements. Jackson (2006); Julien and Barker (2009); Williams and Wavell (2006) disclose that teachers are not teaching information because they themselves are not necessarily trained on the skills. Tan, Kiran and Diljit's (2015) study, which gauge school librarians' perception about their readiness in the implementation of information literacy education in Malaysian secondary schools, found that school librarians indicated a low level of technical readiness when asked to self-assess their information literacy skills.

Another impediment towards effective information literacy instruction is the fact that teachers have to shoulder heavy teaching loads andonly have limited time to teach the skills. Priority is givenon providing classroom instructions. Julien and Barker (2009) and Williams and Wavell (2006) find 'strong emphasis on examination' and 'the need to rush completing subject-matter syllabus' limit teachers from taking the extra time to teach information literacy. Williams and Wavell (2006) summarize that although some teachers 
are concerned about students' competencies to manage information-based tasks, few of them put real efforts to help the students on information literacy.

\section{Teaching Approaches to Teach Information Literacy}

AASL in The information Power: Building partnership for learning (1998) states that effective teaching should be seen as a holistic process involving every aspect of a student's life. Effective teaching needs continuous assessment and responses for a more meaningful life. Various teaching approaches and methodologies have been tried out, used and discussed in numerous studies to teach information literacy, predominantly, through resource-based assignments. Among some of the commonly employed teaching approaches are: (a) scaffolding (Jackson, 2006; LundhandLimberg 2008), (b) coaching (Mokhtar and Majid's (2006); and Mokhtar, Foo and Majid's (2007), and (c) tutors and facilitators (Barrow 1998; Macklin 2001). Jackson (2006) refers to Vygotsky's (1978) constructivism theory in her discussion on scaffolding. Learning is viewed as developing the social level, firstly, between people, and secondly, on the individual level. She recognizes Vygotsky's vision of scaffolding as centred on the interactions between two or more individuals. She explains that Vygotsky's original concept of personal interaction scaffolding can now be expended to online scaffolding in today's technology to allow students to work on their tasks independently. Researchers argue that since students work on their research project and assignments mostly outside of classrooms with no guidance from teachers, the need to provide scaffolding through technology has become more important than ever before (Collins 2006; Gibson 2002; Herrington and Oliver 2000; Jackson 2006). Hannafin et al. (1994) and Hill and Hannafin (2001) discuss four types of scaffolds: (a) conceptual scaffolds, which assist students to understand the topic they are learning, (b) meta-cognitive scaffolds, which encourage students to think about their work, (c) procedural scaffolds, which help students to know how to proceed, and (d) strategic scaffolds, which provide alternative ways to get a work done. A number of information literacy frameworks have been developed, employing a combination of meta-cognitive and procedural scaffolds to guide students through the steps of research process (Eisenberg and Berkowitz 2006; Stripling and Pitts 1998).

Meanwhile, Mokhtar and Majid's (2006) and Mokhtar, Foo and Majid's (2007) work sufficiently prove that information literacy training can be successfully implemented through personalised coaching. Their findings demonstrate that the approach contributes towardsIL development and project better work quality. They advocate personalised coaching as anappropriate pedagogy to enhance learning and to develop information literacy competencies among students. Another teaching approach advocated by researchers to teach information literacy is 'facilitating'. Macklin (2001) for instance, encourage teachers to become facilitators in teaching information literacy through project work and outlines several roles expected from them. They are setting up the problem/situation; balancing student-direction with assistance; contributing knowledge and experiences; creating a pleasant learning environment; and stimulating critical evaluation of ideas. Barrows (1998) similarly discusses some roles teachers can play in teaching information literacy through resource-based learning which include being tutors and facilitators, in which they guide students to inquiry and self-directed learning. The researchers assert that a tutor or a facilitator does not give directions to solve a problem, rather she allows the students to discover their own paths towards solving their problem. They also add that facilitating and coaching methods are among the mostly employed methods to teach information literacy through learning assignments. 


\section{Information Literacy Conception and Understandings, Information Literacy Instruction Approaches}

A number of researchers (Moore 2000; Williams and Wavell 2006) associate teachers' understanding of information literacy and their expertise of the skill, with how they deliver information literacy in classrooms. Moore (2000) reports limited information literacy competencies among the teachers in her study. Although most of the teachers in her study in New Zealand schools believe they have "practical understanding" of information literacy, further analysis shows that almost half of them are unfamiliar with the detail process of finding and using information. This suggests their lack of competencies to teach information literacy. Among the few recent studies attempting to understand the relationship between teachers' understanding of information literacy and how they carry out classroom instructions is by Smith (2013). She conducts a study examining how secondary teachers in Alberta, Canada understand and perceive IL instruction. Smith insists that teachers' personal environments and experiences are responsible in shaping their instructions. She explains that teachers "bring a wealth of experience, a unique body of professional knowledge, and their own assumptions into a classroom" (p.217). Her findings also show that teachers' confusion around the "information literacy" term remains a dominant theme in the study. The participants are found to demonstrate different understanding of the skill set and this results in their various understanding of the skill, and consequently to the different approaches of information literacy instructions. Smith (2013) echoes Williams and Wavell's (2006) outlook and maintain that teachers' individual experience, knowledge, and competencies influence their teaching. She continues that, in addition to that, teachers need to accommodate the external pressures imposed on them by colleagues, school, parents, and government.

\section{OBJECTIVES AND METHOD}

This research aims to understand how teachers conceptualize information literacy and whether these conceptions in any way influence or shape information litearcy integration via history resource-based project instruction in Malaysian schools. The project under study is a nationwide standardized assignment that is compulsory for all secondary three students (grade 9 aged 15) across the country. Abrizah and Zainab (2011) who investigated how students used digital resources for their history school project, point out that resource-based learning in history teaching is an ideal platform to engage students in information literacy through formulating meaningful questions, planning tasks, gathering resources, evaluating information, collaborating with others, and reporting findings.

The study adopts a qualitative approach in the form of a case study method to investigate the phenomenon. The study attempts to answer the following research questions:

a) How has information literacy been conceived by teacher through resource-based learning?

b) How does teacher's conception of information literacy implicate and influence information literacy instruction through resource-based learning?

The participants in the study are five teachers who supervise the secondary three history project. They are Mrs. Anna, Mrs. Brenda, Mr Chan, Mrs. Dora, and Mrs. Emma ${ }^{1}$. They are from four schools in the state of Selangor, Malaysia, namely, Sekolah Amanah, Sekolah

${ }^{1}$ Participants names are fictitious. 
Bijaksana, Sekolah Cendikiawan, and Sekolah Dedikasi ${ }^{2}$, respectively. Two teachers, Dora and Emma come from the same school, that is Sekolah Dedikasi. Emma joins the study later in the middle of the data collection process to supplement data collected from Dora as the latter have difficulty expressing her opinions during the interview.

The study was conducted through a multi-stage, simultaneous data collection procedure over a prolonged one-and-a-half-year time span, detailed in Yu, Abrizah and Saat (2014). Two data collection techniques are used, comprising: (a) interviews with the five teacher participants; and (b) observations of four classroom instructional sessions. The teachers are individually interviewed to probe on their understandings of information literacy, their perceived roles to teach the skills, as well as the instructional methods they employ to teach the history project. A combination of guided or semi-structured interview and indepth interview conversations are employed in the data collection method to ensure that every element and area of information literacy practices are successfully covered in a natural manner through the interviews. As this research is an embedded, single case study as coined by Yin (2003), the unit of analysis is each of the participants, rather than the schools. The data derived from the participants are pooled together as in multiple cases research design. The data analysis is done manually and carried out in two stages. In the first stage (or primary analysis), the analysis, especially data reduction, is made while collecting the data. The focus at this point is to concentrate on the more important aspect of the phenomenon, while the less important ones are discarded. During this period, it becomes apparent that the teacher's understanding of IL, approach to teaching the project, and the students' experiences of the project dominate the project discussion. Meanwhile, the role of teacher-librarian and school library hardly ever surfaced. Therefore, the role of teacher-librarian in supporting the resource-based project is eliminated from the research.

In the second stage, the raw data are processed. Interview transcripts are prepared from tape-recorded interviews, and expended field notes are prepared from scribbled field notes, as well as from recorded video. The data are then closely examined and transferred from interview transcripts and observation notes to data analysis matrices. Here, the data goes through several rounds of data refinement and filtration process, employing Miles and Huberman's (1994) "three steps data analysis: data reduction, data display, and conclusion drawing and verification" approach all through the process. At this point, potential codes are listed and tabulated according to the research objectives and research questions.

\section{FINDINGS AND DISCUSSION}

\section{Teachers' Information Literacy Conceptions}

Data on teachers' understanding of information literacy were meticulously analysed in three stages to facilitate a thorough investigation. During the first stage, teachers' responses to a direct "information literacy conception" question are examined and tabulated. Next, teachers' contextualized information literacy conception involving a broader understanding of information literacy and its relation to the project are studied in the second stage. A third stage of data analysis is conducted where the conceptions from the two previous stages are merged, compared and contrasted, resulting in improved and accurate themes. This leads to the final conception of information literacy.

Six information literacy conceptions are generated under four broad themes in the study. The themes and the conceptions as illustrated in Figure 1:

\footnotetext{
${ }^{2}$ School names are also fictitious.
} 


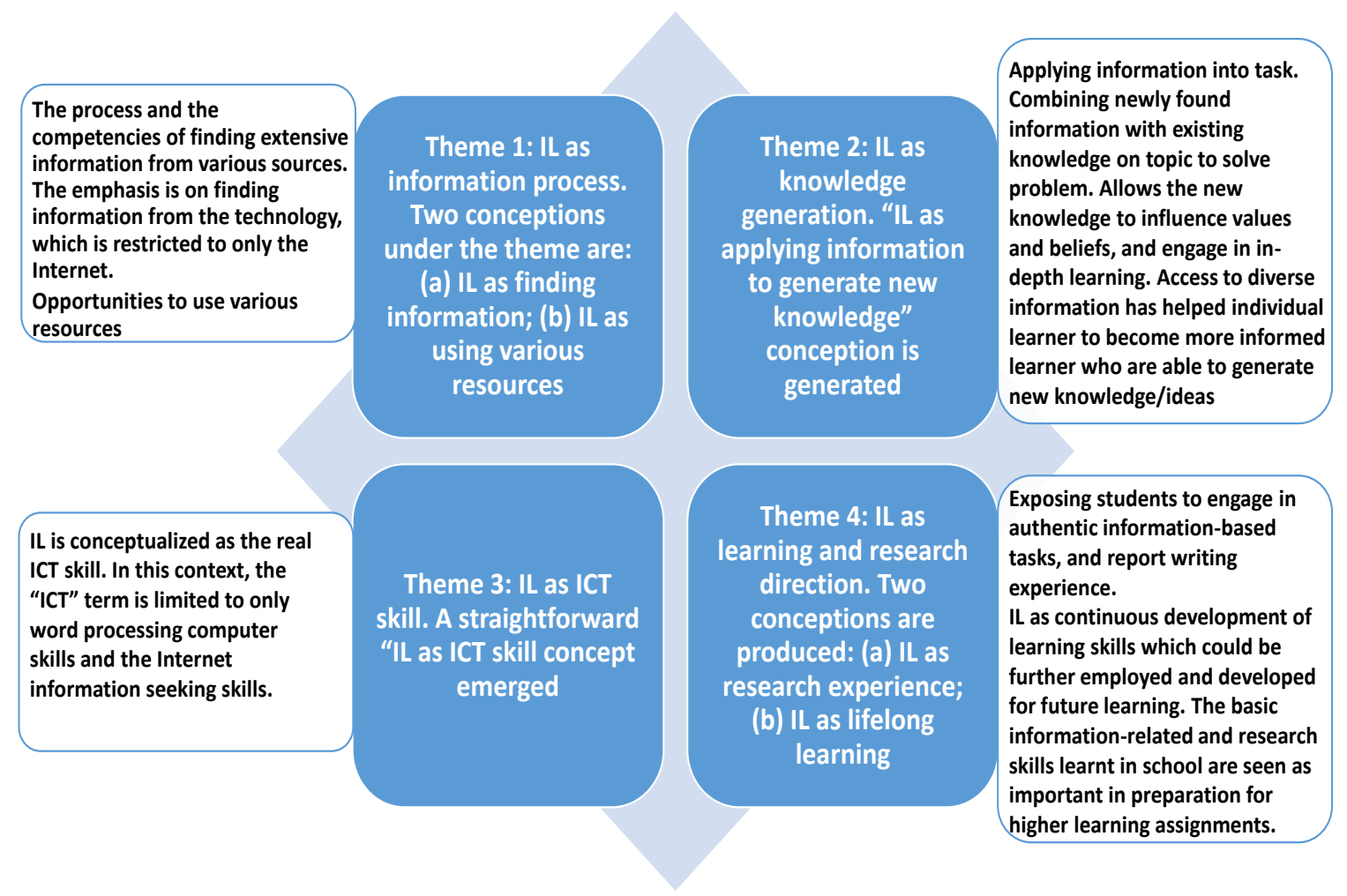

Figure 1: The Six Information Literacy Conceptions Generated Under Four Themes

The first conception, information literacy as finding information, remains one of the most influential conception, with all five teachers discussed information literacy in this direction. This idea is presented through these selected dialogues: "yeah...(the project) is to test the students how to gather (information).." (Chan, L252); and "The project objective is to find the legitimate research evidence (information)" (Anna, L305).

The second conception is information literacy as using various resources. Through this conception, the teachers see the project as a platform for students to engage with and use various resources, for instance, Dora explains; “...without this project, students would depend on text books only...(this project) widens their knowledge." (Dora, L277-278). "They look for resources on the Internet. They (some students) didn't know how to use the Internet prior to this, now they are able..." (Dora, L283-284).

The third conception, information literacy as applying information to generate new knowledge revolves around the development of knowledge and in-depth understanding of subject matter through use of information. This viewpoint is reflected through this dialogue, "the purpose of the project is to gain knowledge, to be open minded...(to achieve that) we have to be exposed to various resources..". (Chan, L694). We can't simply be exposed to one single idea and readily accept it, we have to consider two, three ideas, and then decide (the best ones)...,so, we take other people's ideas and create our own.....generate our own ideas. (Chan, L695-696).

The fourth conception, information litearcy as ICT is a straightforward idea about information literacy being ICT. The teachers readily talk about ICT skills and the ICT classes 
in school to describe information literacy. However, the "ICT" term is limitedly understood as word processing computer skills and the Internet information seeking skills. An example of this viewpoint is expressed here, "these days, the form 1 and form 2 students....they have ICT classes. These classes are compulsory for them. I think it is about ICT usage, like how to use Word, Excel...but I think they also learn how to find information in the class". (Emma, 186-187).

The fifth conception is information literacy as research experience. This view is interpreted as subjecting students to authentic learning and research experience. In expressing their views, the teachers focused on different learning activities of students' research experiences, such as gathering primary data experience, developing research writing skill, and offering students to experiential learning. An example of this outlook discussing developing students' writing skill is presented here: 'the folio (project report) is good to train the students on academic writing because the format is similar to writing a thesis. They have to write the references at the end of the report, like..., writing the authors, etc...the standard format ... (Emma, L419-421).... so they have the basic (in writing research report)". (Emma, L433).

The last conception is information literacy as lifelong learning. This outlook emphasizes on preparation for higher learning, as well as knowledge transfer to new learning environments. These views are presented in these dialogues: "it (project) prepares them to work on assignments when they go to colleges or universities....they will already know how to prepare reports..."(Emma, L465-466); and "After browsing the internet for the first time, they (students) already have the skills and could apply them (on other learning situations), even if it is not for the history subject itself..., they could explore the whole world...". (Chan, L701-702).

The findings show that although the teachers have limited variations in information literacy understanding, they are able to relate it with the domains generally associated with information literacy. Among the famous notions are information literacy as: (a) information seeking, (b) using various resources, (c) in-depth understanding, and (d) applying information.

\section{Information Literacy Conceptions, Teaching Focus, and Instructional Approaches}

Once information literacy conceptions are identified, teachers' teaching focuses and instructional approaches are examined to find out if their understandings of information literacy, in any way, are related to teachers' teaching focuses and instructional approaches in teaching the project. To achieve this, the data are once again scrutinized to identify teachers' teaching focus and the instructional approaches employed. Upon analysis, six teaching focuses and four instructional approaches are identified as supporting the six information literacy conceptions generated earlier. The six teaching focuses that emerged are; (a) information sources and information locating techniques; (b) using at least four different resources (as required by the project marking specification); (c) using various resources to generate in-depth understanding and new knowledge; (d) collecting primary data and research writing skills; (e) Internet information seeking; and (f) cumulative knowledge and preparation for future learning. Meanwhile, the four instructional approaches employed are; (a) briefing/instructing; (b) exploration; (c) facilitating/coaching; and (d) scaffolding.

The information literacy conceptions, teaching focuses, and instructional approaches are then brought together and presented in Table 1 to identify any notable pattern in the three domains. In Table 1, teachers' information literacy conceptions are placed on the left 
column, and the teaching focuses on the right. The instructional approaches are positioned below the information literacy conceptions to facilitate simultaneous comparisons of the three domains. Based on the findings, the first information conception, i.e. information literacy as finding information is found to match one of the teaching focuses, namely "information source and information locating techniques". It becomes immediately clear that the two themes revolve around the same issue of finding and locating information. This suggests that teachers choose to focus on teaching students how to locate information from various sources because they believe that information literacy is primarily about finding information. The emphasis on information source and techniques is evident as teachers have previously briefed the students on possible information sources and techniques to locate information prior to allowing the students to seek for and locate information from various sources independently. They also provide general coaching to assist students with information-seeking activities, and continue to provide additional help through personal coaching and even scaffolding to further assist weak and reluctant students.

The second row of Table 1 demonstrates a strong relationship between the information literacy conception, instructional focus and teaching methods. The second conception is information as using various resources, while the matching teaching focus is "use at least four different information sources" for the project. These two concepts notably revolve around "using various resources". As in the first conception, it is apparent that teachers are concentrating on teaching learning aspects that they believe are important according to their understanding of IL and the project. With regards to this, the teachers demand that students "use at least four different information sources" for the project. To accomplish this, they go all the way to coach/facilitate and scaffold the students into using diversified information sources for their project. To ensure this, the teachers even resort to provide the exact keywords and URL addresses as teaching "shortcuts", as well as making photocopied of printed materials for the weak and reluctant students to make sure that every student fulfill theminimum "four different information sources" rule for the project. Again, this suggests a strong positive relationship between teachers' information literacy conception, teaching theme, and the instructional approaches.

The third information literacy conception is information literacy as applying-informationto-generate-new knowledge, while the accompanying teaching focus is "using various resources to generate in-depth understanding and new knowledge". The instructional approaches employed are "facilitating/coaching"and "scaffolding". While the information literacy conception and teaching focus appear to be less straightforward compared to the earlier conceptions and teaching themes, we can still recognize the positive relationship between the third information literacy conception and teaching focus. This conception entails teachers conceptualizing knowledge generation as a result of experiencing working with information for the project. This outlook is similar to the "using various resources to generate in-depth understanding and new knowledge" teaching focus, in which both themes deal with knowledge expansion and knowledge and skills generation as a possible outcome from in-depth learning through resource-based learning experience.The "facilitating/coaching" and "scaffolding" techniques are accordingly employed to ensure that the "new knowledge" generated from information-related activities is successfully communicated through a completed project report. Among others, teachers are focusing on helping the weak and reluctant students to complete their report and acquire in-depth understanding on the subject area and relevant learning skills from the whole experience.

The fourth conception, namely information literacy as research experience is seen as another well-matched partner to the teaching focus, i.e. collecting primary data and 
research writing skills. Both concepts are evidently focusing on the elements of research experience. Teachers' emphasis on (a) students' primary data collection experience, (b) information seeking activities, and (c) the various aspects of research writing skills, in teaching the project reflects their efforts to teach information literacy, which in this context, is understood as having "research experience". The research-theme conception and teaching focus see teachers employing three different types of instructional methods to suit the different needs of students through exploration, coaching/facilitating, and scaffolding teaching approaches. This is to ensure that every student, both the good and weak/reluctant ones commit themselves into the various "research" activities. The "exploration" approach is mainly employed on the good and average students whom the teachers believe are able to work independently on their work. Teachers, however, continue to provide close assistance to help students with the more difficult areas such as developing interview questions and preparing themselves for the interviews through coaching and facilitating methods. In addition, teachers provide personal scaffolding to help the weak and reluctant students by working together with the students. This entails, preparing rough draft of interview questions together, writing the project report together by preparing short notes to be expanded by students (note expansion technique), and even to the extent of writing the whole notes for students (note-writing) scaffolding approach (employed by teacher Dora).

Next, the fifth conception, information literacy as ICT is coordinated with the "seeking information from the internet" teaching focus. Again, both the information understanding and teaching theme seems to be directly related. In this context, teachers understanding of "ICT" is limited to only word processing computer skills and the Internet information seeking skills. By focusing on teaching students to seek information only from the Internet, the teachers are confirming the idea that information seeking element of information literacy is only about looking for information from the Internet. This also validates the fact that teachers' conception does influence their teaching emphasis, andconsequently, the instructional methods employed.

The last information conception is information literacy as lifelong learning, while the complementary teaching focus is "cumulative knowledge and preparation for future learning". As in the third conception, the two themes involved here are rather general and less straightforward. While lifelong learning is such a broad concept, we can certainly see "cumulative knowledge and preparation for future learning" as reflecting a part of the lifelong learning concept. Through these teaching focuses, teachers see that students continuously develop and upgrade themselves through a series of project work assignments.The teachers, in particular, believethat the students continue to accumulate their knowledge and skills from time to time as they continue to work on new assignments. At least two of the teachers directly associate the project experience with preparation for college and future learning, while three other teachers indirectly suggest that the project experience helps to prepare students to face learning challenges in the future. These conversations truly reflect lifelong learning concept. Two types of learning approaches, namely "exploration" and "coaching/facilitating" are particularly employed to achieve the "cumulative knowledge and preparation for future learning" learning goals. The information literacy conceptions, teaching focuses, and instructional approaches are summarized and presented in Table 1. 
Table 1: Information Literacy Integration Through Project-Based Learning: Conceptions, Teaching Focus, and Project Instructional Approach

\begin{tabular}{|c|c|c|}
\hline & $\begin{array}{l}\text { INFORMATION } \\
\text { LITERACY CONCEPTION }\end{array}$ & TEACHING FOCUS \\
\hline 1. & $\begin{array}{l}\text { IL as finding } \\
\text { information }\end{array}$ & Information sources and information locating techniques. \\
\hline 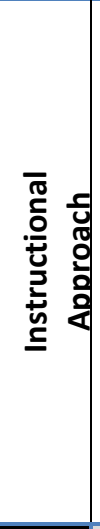 & $\begin{array}{l}\text { Scaffolding: } \\
\text { Briefing/instructing } \\
\text { Exploration } \\
\text { Facilitating/coaching }\end{array}$ & $\begin{array}{l}\text { Providing the exact keywords and URL addresses, and photocopied } \\
\text { materials as "shortcuts" (especially to the reluctant students). } \\
\text { Briefing students on requirement to use resources from at least four } \\
\text { different sources. Advising students on possible information sources to } \\
\text { choose from and discussing the strategies to locate information. } \\
\text { Allows students to seek, locate, and access information from various } \\
\text { information sources independently } \\
\text { Teachers employ two different teaching approaches to assist students } \\
\text { look for information: a) general coaching for good students and b) } \\
\text { personal coaching for weak/reluctant students. Weak/reluctant students } \\
\text { receive extra assistance to help them find information. } \\
\text { Suggests possible information sources to find information }\end{array}$ \\
\hline 2. & $\begin{array}{l}\text { IL as using various } \\
\text { resources }\end{array}$ & Use of at least four different information sources \\
\hline 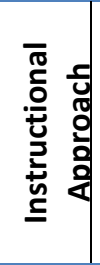 & $\begin{array}{l}\text { Scaffolding } \\
\text { Facilitating/coaching }\end{array}$ & $\begin{array}{l}\text { Providing the exact keywords and URL addresses as "shortcuts" to ensure } \\
\text { students use at least four different sources for the project. } \\
\text { Assist reluctant students by making copies of relevant resources for the } \\
\text { project. } \\
\text { Suggesting possible info. sources and resources to use, suggesting } \\
\text { relevant keywords and websites to locate information from the internet }\end{array}$ \\
\hline 3. & $\begin{array}{l}\text { IL as applying- } \\
\text { information-to- } \\
\text { generate-new } \\
\text { knowledge }\end{array}$ & $\begin{array}{l}\text { Using resources to generate new knowledge. Communicate new } \\
\text { knowledge through project report. Ensures every student has a finished } \\
\text { product. }\end{array}$ \\
\hline 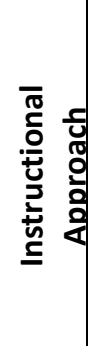 & Facilitating/coaching & $\begin{array}{l}\text { Employ Note writing and note expansion techniques to help reluctant } \\
\text { students write research findings according to the prescribed format. } \\
\text { Prepares short notes and let reluctant/unmotivated students do "note } \\
\text { expansion" to develop notes into full project reports together on the } \\
\text { blackboard. Writes a basic project report on the blackboard and let } \\
\text { unmotivated students who did not care to complete their report to copy } \\
\text { the whole notes. } \\
\text { Coaches students to organize information according to project outline }\end{array}$ \\
\hline 4. & $\begin{array}{l}\text { IL as research } \\
\text { experience }\end{array}$ & Collecting primary data, research writing skills \\
\hline 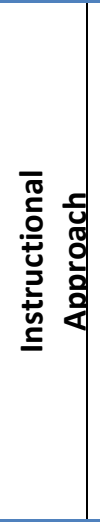 & $\begin{array}{l}\text { Briefing/instructing } \\
\text { Facilitating/coaching }\end{array}$ & $\begin{array}{l}\text { Provides rooms for students to take responsibility of their work and } \\
\text { experience research, e.g. freedom to choose topics and make plans to } \\
\text { work on it. Allows students to embark into research work independently } \\
\text { following initial project briefing and group discussions } \\
\text { Briefing students on requirement to use resources from at least four } \\
\text { different sources. Advising students on possible information sources to } \\
\text { choose from and discussing the strategies to locate information. } \\
\text { Advises and guides students to conduct interview with resource person. } \\
\text { Assists students to organize information sources (writing references). } \\
\text { Checks students' report draft on compilation of resources (referencing). } \\
\text { Checks students' report draft to ensure that they comply with scholarly } \\
\text { research report format. }\end{array}$ \\
\hline
\end{tabular}




\begin{tabular}{|c|c|c|}
\hline 5. & IL as ICT & Seeking information from the Internet \\
\hline 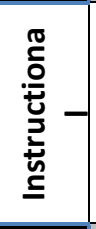 & $\begin{array}{l}\text { Scaffolding } \\
\text { Facilitating/coaching }\end{array}$ & $\begin{array}{l}\text { Provide the exact keywords and URL addresses to provide "shortcuts" } \\
\text { (especially to the reluctant students) to find information } \\
\text { Brings students to school computer lab and requests ICT teacher's help to } \\
\text { supervise students browsing the internet to find information.Suggest } \\
\text { relevant keywords and websites to locate information from the internet. }\end{array}$ \\
\hline 6. & IL as lifelong learning & Cumulative knowledge; preparation for future learning \\
\hline 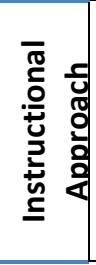 & $\begin{array}{l}\text { Exploration } \\
\text { Facilitating/coaching }\end{array}$ & $\begin{array}{l}\text { Allow students to be self-directed learner, responsible for their own } \\
\text { learning. Allow students to accumulate knowledge and skills from their } \\
\text { learning experience. E.g. Progressively learn to plan, conduct and } \\
\text { communicate research work by working on a series of project work. } \\
\text { Facilitates, monitors, and validates students' work by checking } \\
\text { progressive work from time to time. }\end{array}$ \\
\hline
\end{tabular}

\section{CONCLUSION}

Teachers' conceptions of information literacy are comparable to those generated from other studies, such as Boon, Johnston and Webber (2007), Bruce's Seven Faces of Information Literacy framework, and Williams and Wavell's (2006). There are some similarities and overlapping in the teachers' understanding of information literacy, which tend to revolve around the areas of finding information, ICT skills, research work, and lifelong learning. Examination on these other studies also reveals similar results, although the dimensions of the conceptions tend to vary in sophistication and detail. In general, although the teachers in the present study are able to generate information literacy conceptions that are comparable to those from the other studies, their understandings of the skill aremoresuperficial and lack in richness and sophistication.For instance, the skills are discussed mainly in terms of the physical learning activities and processes within the project experience only and seldom go beyond these experiences.

Based on the pattern between teachers' information literacy conception, teaching focus, and instructional approaches employed by the teachers to teach the project, it can be concluded that teachers' conception of information literacy does influence what they focus to teach and how they approach the instruction. As elaborated in the findings section, it is clear that teachers' information literacy teaching focuses, as well as their project instructional approaches clearly reflect their understanding of the skills required in relation to the project. It is found that the same positive relationship between teachers' information literacy conception, their teaching focuses, and instructional approaches are established in all the six conceptions. This suggests that teachers' understanding of information literacy influence their teaching focuses and approaches to teach the project. As a conclusion, teachers' understanding of information literacy has strong implications on how they teach and integrate the skill through resource-based assignments.

The general findings from this study suggest that teachers focus to teach only information literacy elements that they believe are important for the project. The findings also indicate that teachers' personal understanding of information literacy will influence their focus in teaching the skill, in which they operationalize these understandings through some teaching approaches deemed best to achieve the teaching goals. This suggests the importance of providing adequate information literacy training to the teachers in order for them to help develop students' information literacy skills. 


\section{ACKNOWLEDGEMENT}

This research received no specific grant from any funding agency in the public, commercial, or not-for-profit sectors.

\section{REFERENCES}

Abrizah, A. and Zainab, A.N. 2011. Digital libraries in the classroom: secondary school teachers' conception. Journal of Librarianship and Information Science, Vol. 43, no. 4: 224-236.

American Association of School Librarians (AASL) and Association for Educational Communications and Technology (AECT). 1998. Information Power: Building Partnerships for Learning. Chicago, American Library Association.

American Library Association (ALA). 2008. AASL standards for the 21st century learner. American Association of School Librarians. Available at: www.ala.org/ala/ aasl/aas/proftools/learningstandards/standards.cfm.

Australian and New Zealand Institute for Information Literacy (ANZIIL) and Council of Australian University Librarians (CAUL). 2004. Australian and New Zealand Information Literacy framework. Library Publication, University of South Australia, South Australia.

Bawi, Z. A. 2002. Implementing technology in schools: perception of principals towards the implementation of Malaysian Smart School. Ubpublished Master thesis. International Islamic University Malaysia, Kuala Lumpur, Malaysia.

Barrow, H.S. 1998. The essentials of problem-based learning.Journal of Dental Education, Vol. 62, no. 9: 630-633.

Boon, S., Johnston, B. and Webber, S. 2007. A phenomenographic study of English faculty's conceptions of information literacy.Journal of Documentation, Vol. 63, no. 2: 204-228.

Bruce, C. 1997. Seven Faces of Information Literacy in Higher Education. Brisbane: QUT. Available at: http://sky.fit.qut.au/ bruce/inflit/faces1.htm.

Chan, F.M. 2002. Developing information literacy in the Malaysian Smart Schools: Resource-based learning as a tool to prepare today's students for tomorrow's society. School Libraries for a Knowledge Society: Proceedings of the 31st Annual Conference of the International Association of School Librianship and the sixth International Forum on Research in School Librarianship. Petaling Jaya, Malaysia. pp.203-215.

Collins, A. 2006. Chapter 4.Cognitive Apprenticeship. In R. K. Sawyer (Ed.), The Cambridge Handbook of the learning sciences: Cambridge University Press.

Eisenberg, M. and Berkowitz, B. 2006. The Big6: Information litracy for the information age. Available at: http://www.big6.com/.

Gibson, M.R. 2002. A qualitative investigation for designing intermediate (Grades 4-6) information literacy instruction: Integrating inquiry, mentoring, and on-line resources. PhD thesis, University of Kentucky.

Hannafin, M., Hill, J. and Land, S. 1994. Learning in open-ended environments: Assumptions, methods, and implications. Educational Technology, Vol. 34, no. 8: 48-55.

Hart, G. 2000. Project work as a vehicle for information literacy education in a circuit of South African primary schools. Proceedings of the 66th IFLA Council and General Conference, Jerusalem, Israel 13-18 August 2000. Available at: http://ifla.queenslibrary.org/IV/ifla66/papers/074-133e.htm.

Herrington, J. and Oliver, R. 2000. An Instructional design framework for authentic learning environments. Educational Technology Research \& Development, Vol. 48, no. 3: 2348. 
Hill, J.R. and Hannafin, M.J. 2001. Teaching and learning in digital environment: The resurgence of resource-based learning. Educational Technology Research and Development, Vol. 49, no. 3: 37-52.

Jackson, C. M. 2006. The high school library web site: Scaffolding information literacy skills. $\mathrm{PhD}$ thesis, Illinois State University, Illinois.

Julien, H. and S. Barker. 2009. How high-school students find and evaluate scientific information: A basis for information literacy skills development. Library \& Information Science Research, Vol. 31: 12-17.

Lund, A.and Limberg, L. 2008. Information practices in elementary school. LIBRIES Library and information science Research Electronic Journal, Vol. 58, 92-101.

Macklin, A.S. 2001. Integrating IL using Problem-based learning.Reference Services Review, Vol. 29, no. 4: 306-313.

Mc Kenzie, J. 2000. Beyond Technology: Questions, Research, and the Information Literate school, Bellingham, WA: FNO Press, 2000.

Meyers, E. M. and Eisenberg, M. B. 2008. Information Behavior of Grade 9 Students: More and Less Savvy than You Might Think. The International Association for School Librarianship (IASL) Conference, August 3-7, 2008, Berkeley, CA.

Miles, M. and Huberman, M. 1994. Qualitative data analysis: An expanded sourcebook (2nd. Ed.). Thousand Oaks, CA: Sage.

Mokhtar, I. A., Foo, S.andMajid, S. 2007. Guide me, show me: Personalised coaching as a means of instilling information literacy competencies in students.LIBRIES Library and Information Science Research Electronic Journal, Vol. 17, no. 2: 1-19.

Mokhtar, I. A., and Majid, S. 2006. Information literacy education in the context of project work: Application of multiple intelligences and mediated learning. Proceedings of the Asia-Pacific Conference on Library \& Information Education \& Practice 2006 (A-LIEP 2006) Singapore.

Moore, P.A. 2000. Towards information literacy: One school's journey. Wellington, NZCER.

Moore, P. (2002). An analysis of information literacy education worldwide. White Paper prepared for UNESCO, the U.S. National Commission on Libraries and Information Science, and the National Forum on Information Literacy. Information Literacy Meeting of Experts, Praque, The Czech Republic.

Probert, E. 2009. Information literacy skills: Teacher Understandings and Practice. Computers \& Education, Vol. 53, 24-33.

Smith, J. K. 2013. Secondary teachers and information literacy (IL): Teacher understanding and perceptions of IL in the classroom. Library \& Information Science Research, Vol. 35, 216-222.

Stripling, B.K. and Pitts, J.M. 1998. Brainstorms and Blueprints: Teaching Library Research as a Thinking Process. Eaglewood, CO: Libraries Unlimited, Inc.

Tan, S.M., Kiran, K. and Diljit, S. 2015. Examining school librarians' readiness for information literacy education implementation. Malaysian Journal of Library \& Information Science, Vol. 20, no. 1: 79-97

United Nations Educational, Scientific and Cultural Organization (UNESCO). 2007. Understanding Information Literacy: A Primer. Paris, Information Society Division, Communication and Information Sector Paris.

Vygotsky, L.S. 1978. Mind in Society: The development of higher psychological processes. Cambridge, MA: Harvard University Press.

Webber, S and Johnston, B. 2000. Conceptions of information literacy: new perspectives and implications. Journal of information science, Vol. 26, no. 6: 381-397.

Williams, D. and Wavell, C. 2006. Information literacy in the classroom: Secondary school teacher's conceptions. Final report on research funded by Society for Educational Studies.Research Report 15.The Robert Gordon University. 
Yin, R.K. 2003. Case study research; Design and methods (3rd. Ed.).Thousand Oaks, CA: Sage.

Yu, H., Abrizah, A. and Saat, R.M. 2014. Overcoming time and ethical constraints in the qualitative data collection process: A case of information literacy research. Journal of Librarianship \& Information Science, Vol. 46, no. 3: 243-257.

Yu, H., Noordin, S. A., Mokhtar, S. A.and Abrizah, A. 2011. Integrating Information literacy instruction (ILI) through resource-based school projects: An interpretive exploration. Education for Information, Vol. 28, no. 2-4: 247-268. 